\title{
On the taxonomic identity of Arisaema pierreanum Engl. (Araceae) in Vietnam
}

\section{- Van Hong Thien}

Industrial University of Ho Chi Minh City

Institute of Tropical Biology, Vietnam Academy of Science and Technology

- Nguyen Phi Nga

University of Science, VNU-HCM

- Luu Hong Truong

Southern Institute of Ecology, Vietnam Academy of Science and Technology

(Received on June $5^{\text {th }} 2015$, accepted on $26^{\text {th }}$ September 2016 )

\section{ABSTRACT}

The taxonomic identity of the rare Arisaema pierreanum Engl. has been disagreed by botanists, mostly due to the lack of diagnostic characteristics of its female inflorescence. In this paper, a detailed description of the species is provided based on our new living collections

Keywords: Araceae, Arisaema pierreanum, Arisaema roxburghii, Arisaema harmandii, Ba Den Mountain, Vietnam

\section{INTRODUCTION}

Arisaema pierreanum Engl. was first described in 1920 by Engler based on Pierre's collection from Ba Den Mountain, southern Vietnam in 1869 [2]. No more collections of this species were known until a recent report by Nguyen et al. (2014), who revisited the mountain to collect the plant in 2013 [9]. During this duration, the taxonomic status of the species was disagreed by other authors. Gagnepain (1942) [4], Murata (1984) [7] accepted it as a good species. However, in their recent revision of the genus, Gusman and Gusman (2006) reduced it to be a synonym of $A$. roxburghii Kunth because: (1) Nicolson (1999) determined that $A$. harmandii Engl. was synonym of $A$. roxburghii, and (2) they supposed that the types of A. pierreanum and $A$. harmandii were collected from the same place, i.e. Ba Den Mountain, NW of Ho Chi Minh City in southern Vietnam, and thus both taxa were conspecific [6]. Nguyen et al. (2014) disagreed from the type location, Ba Den Mountain, by which we reconfirm its specific status and eliminate a former question about its possible conspecific form of A. roxburghii Kunth and A. harmandii Engl. with Gusman and Gusman (2006) by accepting A. pierreanum as a good species based on its male spadix with long cylindrical, light conical fertile portion and stamens not in groups and densely arranged [9]. However, only the character "stamens not in groups" appears to be of diagnostic importance to distinguish $A$. pierreanum from $A$. roxburghii as the others vary in the later species as stated in Gusman \& Gusman (2006), especially in its populations observed in Malaysia. A clear delimitation of $A$. pierreanum, therefore, needs supplemental information, especially on the female inflorescences that have been missed in both collections by Pierre in 1869 and Nguyen et al. in 2013.

During our re-survey of the Araceae in southern Vietnam, we successfully sampled both living male and female inflorescences of $A$. pierreanum from the type location, Ba Den Mountain, in June 2015 (Thien93, SGN, PHH).

Trang 52 
Our examination of the collected living materials indicates its distinct characteristics and therefore we re-describe it here with the updated information based on our collection.

\section{MATERIALS AND METHODS}

\section{Materials}

Plant specimens: Arisaema pierreanum Engl.: Vietnam. Tay Ninh Province, Ba Den Mountain: Pierre sine num (holotype B_10_0279782, B, image seen; isotypes P00141040, P001410401, P, images seen), April 1869, $500 \mathrm{~m}$ in elevation; Van Hong Thien Thien93 (SGN, PHH), 20 June 2015, approximate coordinates $11^{\circ} 22^{\prime} 28^{\prime \prime} \mathrm{N}$, $106^{\circ} 10^{\prime} 37^{\prime \prime} \mathrm{E}$, at ca. $352 \mathrm{~m}$ in elevation. On humus soils on rocks, under evergreen tropical forest canopy. Arisaema harmandii Engl.: Vietnam. Cochinchine: Pierre 191 (P00141023, image seen).

\section{Methods}

Plant specimens were collected and processed following the Kew Botanic Garden protocols (Bridson \& Forman, 1999).

\section{RESULTS AND DISCUSSION}

Taxonomic treatment

Arisaema pierreanum Engl., 1920. Pflanzenr. 73 (IV. 23F): 159 [2] (Fig 1)

Gagnepain, 1942. Fl. Gén. Indoch.6: 1186 [4]

Murata, 1984. Journ. Fac. Sci. Univ. Tokyo 3(13): 467 [7]

Govaertet al., 2002. World Checkl.Bibliogr.Arac. 201 [5]

Nguyen V. D., in N.T. Ban, 2005."Araceae" Checkl.Pl. Vietn.3: 881 [10]

Gusman and Gusman, 2006. The genus Arisaema: 221 [6]

Nguyen et al., 2014. AroideanaVol 37E No 2: 88 [9]
Type: Vietnam. Tay Ninh Province, Ba Den Mountain: Pierre sine num (holo. B_10_0279782, B, image seen; iso.P00141040, P001410401, P, images seen), April 1869, 500 m in elevation.

Herb deciduous, 0.3-1.2 $\mathrm{m}$ high. Subterranean, sub-globose stem $3-4 \mathrm{~cm}$ in diameter and $1.5-2 \mathrm{~cm}$ high. Leaves 1 or 2 ; petioles sheathing into dark red pseudostem at lower part, free above; pseudostem 7-30 cm long, ca. $1.5 \mathrm{~cm}$ in diameter at base, dark red; free petiole 14-40 cm long, ca. $0.7 \mathrm{~cm}$ in diameter at base, ca. $0.5 \mathrm{~cm}$ in diameter at apex, dark red; leaf blade trifoliolate, leaflets $15-28 \mathrm{~cm}$ long, 6-14 cm wide, thin, glabrous, dark green above, pale green under side, margin undulate, apex acuminate with ca. $1.5 \mathrm{~cm}$, midrib impressed adaxially and prominent abaxially, lateral veins $12-14$, collective vein at $0.4-0.5 \mathrm{~cm}$ from margin, central leaflet ovate, with base rounded, petiolule $1.2-2 \mathrm{~cm}$ long, lateral leaflets asymmetrical, with base rounded, petiolule ca. 1 $\mathrm{cm}$ long. Inflorescence solitary, emerging from pseudostem; peduncle shorter than petiole, 13-30 $\mathrm{cm}$ long, ca. $0.5 \mathrm{~cm}$ in diameter, dark red; spathe tube cylindrical, slender, $5-3 \mathrm{~cm}$ long, $2.5-3 \mathrm{~cm}$ in diameter, expanded at spathe mouth, white or light greenish on both surfaces, yellowish near spathe limb; spathe limb curved over mouth, 9-11 $\mathrm{cm}$ long, 4.5-5 $\mathrm{cm}$ wide, very bright yellow on both surfaces, spathe tip acute, ending in a ca. 1 $\mathrm{cm}$ thread. Female spadix appendix 4-5 cm exserted from spathe mouth, naked, filiformed; female part longer than appendix, 5-6 cm long, 1 $\mathrm{cm}$ wide, cylindrical, pistils densely arranged; ovaries ovoid, green, ca. $3 \mathrm{~mm}$ in diameter, 3.5-4 $\mathrm{mm}$ high, 1-locular, with 5-6 ovules; ovules ca. $2.5 \mathrm{~mm}$ long, basal placentation, translucent, bottle-shaped. Male spadix appendix $2.5-3 \mathrm{~cm}$ exserted from spathe mouth, naked, filiformed, light yellow; male part shortly stiped, ca. $0.3 \mathrm{~cm}$ 
long, densely arranged, light yellow; thecae light yellow and dehiscent by elongated pore.

\section{Discussion}

All collections of Arisaema pierreanum obviously support its placement in the section Fimbriata [6] (recently recommended by Murata (2013) to be moved to the sect. Attenuata [8]) as this species has: deciduous habit, sub-globose, tuberous, subterranean stem; rooting around the central shoot only; 1-2 bilaterally symmetrical leaves; trifoliolate leaf blade; and glabrous, subulate and slender spadix appendage. In this section, A. barbatum, A. maxwellii, $A$. condaoense, A. pachystachyum, A. roxburghii (syn. A. harmandii) and A. sizemoreae were reported to have yellow spathes like that of $A$. pierreanum [6]. However, unlike A. pierreanum, A. barbatum and A. pachystachyum have yellow green rather than true yellow spathes and neuters or projections on the spadix appendix. $A$. sizemoreae has very yellow spathe but it is different from A. pierreanum in having spadix appendix with a brush of yellow-green upright fleshy bristles. In fact, $A$. pierreanum appears to be the most similar to $A$. maxwellii and $A$. condaoense, but it is distinguishable from the two later in having a combination of always auriculate spathe limb, long and glabrous male and female spadix appendices, non-grouping stamens and yellow synandria. These characters also make $A$. pierreanum different from $A$. roxburghii (syn. A. harmandii). Furthermore, although the limb of the later is sometimes auriculate, it is actually translucent - a character which is not seen in A. pierreanum. Based on the descriptions twice by Engler (1898 \& 1920) [1, 2 ], especially the figure 29 in page 164 (Engler, 1920), and examination of the specimens mentioned above and our collections, we do not doubt that $A$. harmandii is a synonym of $A$. roxburghii [6] and thus it is not a synonym of $A$. pierreanum. In fact, we have collected $A$. roxburghii in the coastal Kien Luong Karst Hills (Kien Giang Province) and Cambodia-bordered That Son Mountains (An Giang Province), both in the Mekong Delta; these collections match Harmand's (1875-1877) in all characters and in locality-i.e. the "mouths of the Mekong River" [1, 2]. Meanwhile, Ba Den Mountain, where $A$. pierreanum has been collected by Pierre in 1869 , Nguyen et al. in 2013 and by us in 2015, is a famous religion and tourist location in Tay Ninh Province. It is located in the southeastern Vietnam but isolated from the Mekong Delta. These facts do not support the idea that the types of A. harmandii and A. pierreanum were collected from the same location [6].

\section{CONCLUSION}

With updated information on its both male and female inflorescences collected from the type location, A. pierreanum is obviously distinct from its close species including $A$. roxburghii, and therefore it should be accepted as a good species.

\section{Trang 54}



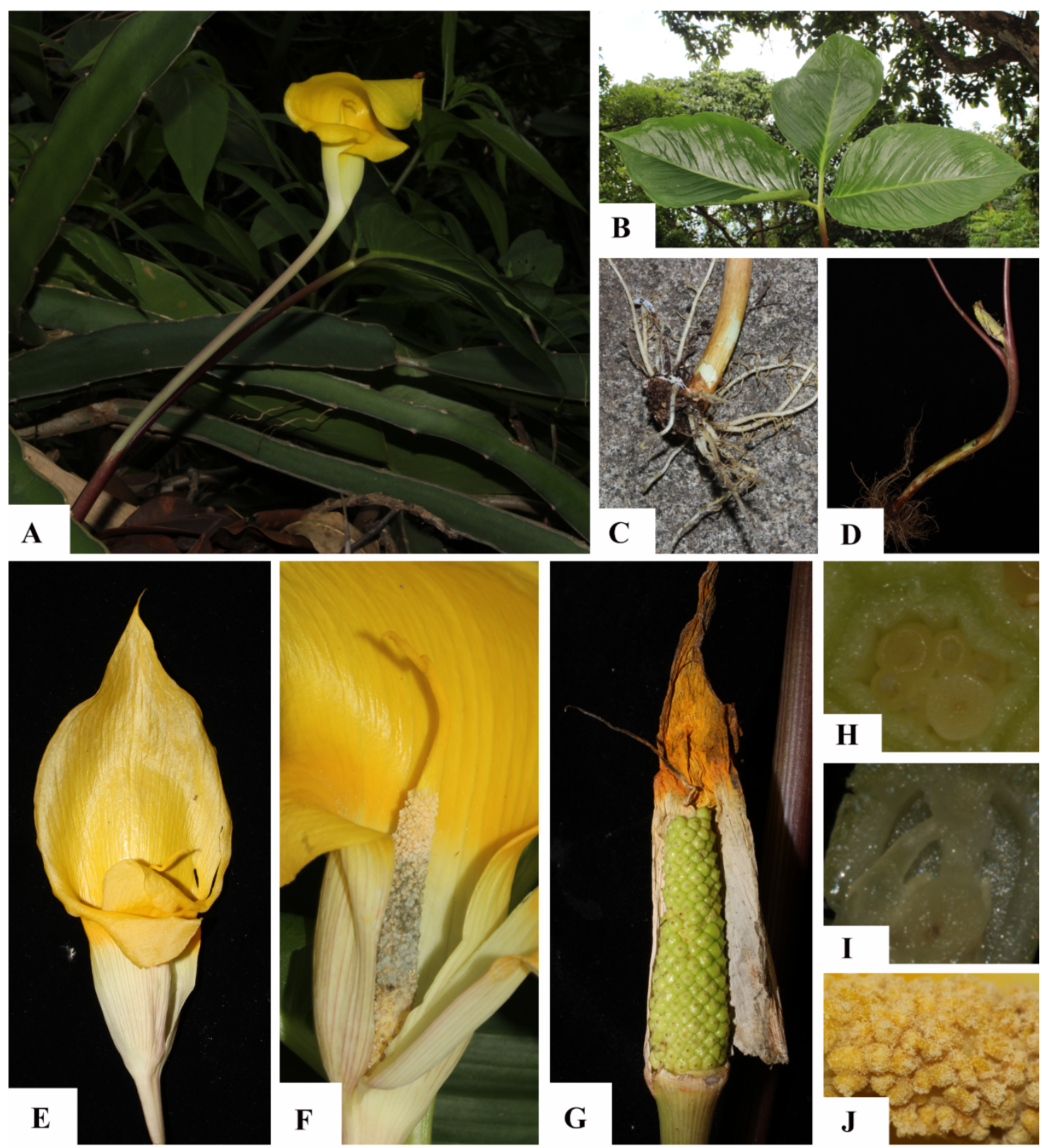

Fig. 1. Arisaema pierreanum. A) The species in habitat, B) Leaf blade, C) Tuber, D) Cataphylls and pseudostem, E) Spathe, F) Male spadix (withering), G) Female spadix, H) Cross section of ovary, I) Longitudinal section of ovary, J) Synandria 


\section{Vị trí phân loại của loài Arisaema pierreanum Engl. (Araceae) ở Việt Nam}

\section{- Văn Hồng Thiện}

Trường Đại học Công nghiệp Tp.HCM

Viện Sinh học Nhiệt Đới, Viện Hàn Lâm Khoa học \& Công nghệ Việt Nam

\section{- Nguyễn Phi Ngà}

Trường Đại học Khoa học Tự nhiên, ĐHQG-HCM

- Lưu Hồng Trường

Viện Sinh thái học Miền Nam, Viện Hàn Lâm Khoa học \& Công nghệ Việt Nam

\section{TÓM TẮT}

Các nhà phân loại thực vật đã không thống nhất về danh pháp của loài hiếm Arisaema pierreanum Engl., thuộc ho Araceae, bởi do thiếu thông tin về các đặc điểm phân loại quan trọng ỏ phát hoa cái. Trong bài này, chúng tôi mô tả chi tiết về loài dựa trên nhũng mẫu vật turơ vì̀ thu

thập được tù̀ vùng núi Bà Đen, noi đã thu mẫu chuẩn của loài cách đây 146 năm. Qua đó, chúng tôi xác nhận lại tình trạng phân loại của loài này và loại trù khả năng đồng danh của loài với $A$. roxburghii Kunth và A. harmandii Engl.

Tù khóa: Araceae, Arisaema pierreanum, Arisaema roxburghii, Arisaema harmandii, Núi Bà Đen

\section{REFERENCES}

[1].A. Engler, Arisaema. In: Beitrage zur Kenntnis der Araceae VII. Araceae novae Asiae tropicae et subtropicae. Bot. Jahrb. Syst. 25, 27-28 (1898).

[2].A. Engler, Araceae, Das Planzenreich 4, 23F, 159 (1920).

[3].D. Bridson, L. Forman, The Herbarium Handbook-Third Edition, Royal Botanic Gardens, Kew, UK (1999).

[4].F. Gagnepain, Aracées, Fl. Gén.Indoch. 6, 1182-1191 (1942).

[5].R. Govaert, D.G. Frodin, World checklist and Bibliography of Araceae (and Acoraceae), Royal Bot. Gard. Kew, Richmond. UK, 201 (2002).

[6].G. Gusman, L. Gusman, The genus Arisaema. A Monograph for botanists and nature lovers, 2nd ed. A.R.G. Gärtner Verlag Kommanditgesellschaft, Ruggell (2006).

[7].J. Murata, An attempt at an infrageneric classification of the genus Arisaema (Araceae). J. Fac. Sc. Univ. Tokyo sect. 3, 13, 431-482 (1984).

[8]. J. Murata, H. Nagamasu, H. Ohashi, A nomenclatural review on the infrageneric classifications of Arisaema (Araceae), J. Jpn. Bot, 88, 36-45 (2013).

[9].V.D. Nguyen, V.T. Tran, C.S. Le, T.V.A. Nguyen, Rediscovery of Arisaema pierreanum Engl. after 145 years, and its current status, Aroideana, 37E, 2 (2014).

[10]. V.D. Nguyen, in N.T. Ban, Araceae, Checklist of plants of Vietnam 3, Agriculture Publishing House, 881 (2005).

\section{Trang 56}

